\title{
Standardized Testing In The Case Of China And The Lessons To Be Learned For The U.S.
}

Osman Özturgut, Ph.D., University of the Incarnate Word, USA

\begin{abstract}
The Chinese have been using standardized testing for centuries. Ancient Greeks have tried it for centuries since $5^{\text {th }}$ and 4th BC. There is no evidence that they have become successful in educating their children through an imperial or elitist system. The impact of standardizing the education on a nation is significant. This is not only true for not being able to cultivate creative and innovative youth and thus a society, but also has significant impact on the economy as well. China example may help justify and clarify the direction we are heading in educating our nation. This paper reflects on the impact of standardized testing on China and explains the need to redirect our efforts within our educational system.
\end{abstract}

Keywords: standardized testing; Chinese education

\section{INTRODUCTION}

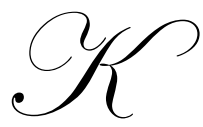

andel (1881-1965) is the most widely recognized leader and founder of modern comparative education. He asserted that the direction of education in democratic nations ought to be "borrowed and adjusted" within the cultural context of each nation. He further argued that, "so many of the problems in education are today common to most countries; in their solution certain common principles . . . are involved; the practical outcomes may, however, differ because of differences in tradition, in social and political principles, and in cultural standards" (Kandel, 1936, p. 401). As Kandel (1933) suggested, the problems and purposes of education have in general become somewhat similar. It is therefore important to learn from the experiences of other cultures and nations.

Our nation is currently experiencing an educational reform in the case of the strong inclination towards standardizing testing system. It is therefore important to look at the examples from other countries and learn from their experiences. The phenomenon of standardized testing is not new and unique to our nation. It is being practiced around the world, especially in East Asia (more specifically, China), since 605 A.D. In this paper, the author will identify some of the issues with standardized testing and its future impacts by analyzing the standardized testing practices in China.

\section{ASSUMPTIONS}

Schools use standardized testing scores to group students in instructional tracks, to identify learning disabilities, to promote, to guide the curricula, and to set a baseline for college admissions. The purpose of such a system is to provide accountability within an education system and in a way to evaluate teacher and institutional effectiveness. One of the original reasons for the introduction of mandated standardized tests was to reduce the effects of patronage (Madaus, 1991).

This paper assumes that the expansion of standardized testing will have further cultural, economic, political, and social impacts on a nation's future. 
For the purpose of this paper, standardized testing refers to generic tests that are uniformly administered and scored. There two types of tests: 1) Criterion-referenced tests, where the individual results are compared a specific performance level, and 2) norm-referenced tests, where the individual results are used to rank students and identify the ones with special needs. Author's assumptions are:

1. Standardized testing will lead to a national curriculum. States and the Federal Government will not be able to keep up with the diversity within the schools and curricula, therefore, request a national curriculum. Federal Government will benefit from a national curriculum. Establishing and maintaining control within the education system and the society can be achieved through a national curriculum. This is not only an issue for students but also for teachers and administrators both in K-12 and higher education. It will create a uniformity and standardization of teacher and educational leader preparation. National Committee for the Accreditation of Teacher Education (NCATE) standards are widely accepted and promoted throughout the United States. Such tests, as SAT and ACT create and promote the need for further standardization of educational requirements and qualifications. The No Child Left Behind (NCLB) Act of 2001 will further cause a curricular conformity and reshaping of how we train teachers.

2. Standardized testing will lead to a national curriculum where the products (students) will be conformist. Nation-states utilize national curricula and uniform education system to control the masses. If government designs and controls the curriculum, determines the score for the best-educated student, it will be able to control the minds of its citizens. This is in one sense helpful in maintaining the nation-state, carrying the nation further, creating a national identity, and instilling patriotic and civic values in the minds of the children. In Foucault's (1984) words:

The examination combines the techniques of an observing hierarchy and those of a normalizing judgment. It is a normalizing gaze, a surveillance that makes it possible to qualify, to classify, and to punish. It establishes over individuals a visibility through which one differentiates them and judges them. That is why, in all the mechanisms of discipline, the examination is highly ritualized. (p. 197)

However, creation of a nation with a set curricular system where every individual is tested on the government mandated knowledge for one reason or another, innovation and creativity will become lesser values to be learned and practiced.

3. Because of the emphasis on testing, the demand for supplementary programs (i.e. after-school programs, private tutoring) will increase. There will be more programs providing supplementary tutoring for standardized test. Therefore, the "Education for All" will no longer be valid and it will be that further education is only for the privileged. Only the parents that are able to afford such test-preparation programs will be able to send their children to better high schools and colleges. Elitism will prevail within the education system. This will impact the social structures but with the additional expense on such programs, families will struggle to manage their lives while incorporating such expenses into their income.

4. When supplementary programs become necessary to pass the tests, schools will no longer be interested in educating our children but simply focusing on the test scores. With the increasing role of the supplementary programs, their accountability will be reduced down to only keeping the students safe in schools until it is time for them to attend these programs. Only the students with more affluent parents will benefit from such services, and the public schools will be left with students in low-socioeconomic category. An elitist education system will be created and promoted with minimal or no accountability for the schools.

5. Standardized testing is and will further be biased. Standardized tests ignore race, gender, disability, culture, age, class, and linguistic differences. With its social, cultural, political, and economic structure, such tests, standardized tests in diverse nation-states are unreliable. These tests are structured with outdated educational theories. These theories assume that cognition and learning can be structured in a way that it is isolated and de-contextualized from the actual situations (Resnick \& Resnick, 1989). Furthermore, standardized test lack instructional and curricular validity (Linn, 1987; Wiggins, 1989). These tests not only ignore the realities we live in, they also widen the social, cultural, and educational gap within the nation. 


\section{SIGNIFICANCE}

As iterated earlier, standardized testing is not a new phenomenon. The Chinese have been using is for centuries. Ancient Greeks have tried it for centuries since $5^{\text {th }}$ and 4 th BC. There is no evidence that they have become successful in educating their children through an imperial or elitist system. The impact of standardizing the education on a nation is significant. This is not only true for not being able to cultivate creative and innovative youth and thus a society, but also has significant impact on the economy as well. China example may help justify and clarify the direction we are heading in educating our nation.

\section{BRIEF HISTORY OF STANDARDIZED TESTING}

We can trace the roots of the standardizing testing back to ancient China where, government jobs were assigned according to the scores of tests, mainly with questions about Confucian philosophy and poetry. This Imperial examination system, formally started during the Sui Dynasty in 605 B.C., consisted of military strategy, civil law, revenue and taxation, agriculture, geography, and the philosophical works of Confucius and his disciples. They designed tests for various levels of assignments within the government. Each degree required a more specific content knowledge.

In Ancient Greece, Socrates had used a system where he tested his students through dialogue. There were not necessarily right or wrong answers but creation of more dialogue and a higher knowledge was the purpose. Essay type tests were favored over multiple choice methods. With the Industrial Revolution, children were led to a more formalized schooling system where they were forced to study a set curriculum. Increasing number of students in schools created a need for a more practical systems and standardized testing became a standard practice. Psacharopoulos and Tassoulas (2004) explain that according to a Greek legend, "Procrustes was a robber in Attica. He had an iron bed on which he forced his victims to lie. If the victim was shorter than the bed, Procrustes stretched him by hammering or racking his body to fit the bed. If the victim was taller than the bed, the robber mutilated the body to the bed's dimensions" (p. 250).

\section{RATIONALE}

We cannot predict the future without looking at the past. In this case, other than the weaknesses of a system where students are assigned grades, instructional tracks, and granted admission based on their scores, it is important to analyze the issue of further impact on the future of our children and the country. Extensive reliance of standardized testing to help our schools and children has not been the best practice over the years. Ironically, the heavier our reliance on testing, the more we stay behind in our comparisons with other countries in terms of our success with formal schooling of our children.

This system further led to creation of SAT in 1926 as the Scholastic Aptitude Test, and then later ACT in 1956 (American College Testing) as alternatives and competitors. We now see a growing trend in the popularity of standardized testing where the schools have to follow the guidelines identified in the NCLB of 2001. NCLB mandated annual testing of students to demonstrate the improvement in their literacy and math skills as well as other core competencies.

Such testing systems do not necessarily produce valid and reliable scores, but also hinders the work of our teachers and administrators. Once their pay becomes tied to producing students with higher scores in such tests, we mainly become a nation of test-takers with a need for increasing skills in test taking. Our schools will not necessarily be able to cope with this change when education the future generations of our nation. Therefore, it makes sense that we look at some examples from around the world where the standardized testing has the most influence in how a nation is shaped.

\section{CASE OF CHINA}

China has the longest history of standardized testing in the history. Imperial Examination can be traced back to the Western Zhou Dynasty (11th century BC-771 BC). Its origins extend back to Han Dynasty (260 BC-AD 
220) with Sui Dynasty (AD 580-618) implementing it. Formal establishment was during Song Dynasty (AD 9601279). During Ming (AD 1368-1644) and Qing(AD 1644-1911), these examinations were highly regulated and promoted. It was not until 1905, it was the common practice (Niu, 2007). The traditional education system was devoted to the study of Confucian classical texts for the Imperial examinations. Prospective candidates learned definite rules of conduct which they applied, on appointment as officials, to the concrete conditions of everyday life. Both clan and state schools were designed to train youth for the Civil Service Examinations, and Imperial rulers did not envisage the extension of a general education system to a wider public.

Despite a short period of Communist rule since 1949, Confucian ideology is still a strong force in the People's Republic of China (P.R.C.) today. Taking the family as a model for society at large, Confucianism is basically authoritarian, emphasizing hierarchical principles and status differences. Mao accepted the basic Marxist principle that education is part of the superstructure of society and infrastructure of economy. He further believed that education was a propaganda tool of the ruling class and served its interests only. He had solid grounds for his belief. In feudal China, 90 percent of the population was peasants, but education was controlled by the landlords, and the ideology within the educational system represented that of the landlord class. Mao argued that in a socialist society, education should be turned to serve the interests of the workers and peasants.

The educational system was to create individuals that were both "red and expert" (Kwong, 1997, p. 48). Redness referred to the possession of the Communist outlook. It was the duty of the educational system to instill into the young political awareness through strengthening their ideological and political work. Therefore, both students and intellectuals should study hard. They should study Marxism, current events, and political problems, which will then help them make progress both ideologically and politically. "Not to have a correct political viewpoint is like having no soul" (p. 44). After the establishment of the Republic, he saw the aim of education as socialist construction. His emphasis shifted from nationalism to socialism: "Our educational policy must enable everyone who receives an education to develop morally, intellectually, and physically and become a well educated worker imbued with socialist consciousness" (Tse-tung, 1935, p. 459).

Education, in this sense, was a way to create conformist citizens with strong emphasis on national identity through a national curriculum. In today's China, students must prepare for "Gaokao", the multi-level national test to enter colleges. Their scores will determine if and where they will study and what they will study. It is not necessarily what they would want to study but rather an aggressive competition to enter a college, whatever the major is, and graduate with a diploma to be further able to compete for government jobs. Even though ACT and/or SAT are not only factors determining the further education of a student in China, "gaokao" score is the only one deciding who would receive a "good" education at a public school for the Chinese youth. Current political, economical, social, and cultural environment in China has been significantly influenced by standardized testing, confirming the author's assumptions.

\section{CONCLUSION}

Chinese leaders are encouraging the creation of a more innovative and creative youth. They are encouraging public schools to provide a more liberal education preparing student for global leadership roles. And the U.S. is going towards an elitist and backward education system where conformist citizens are validated and rewarded. In the case of China, author's assumption that standardized testing will lead to a national curriculum where the products (students) will be conformist and easy to control is confirmed. Additionally, with China's social, cultural, and linguistic diversity, the assumption that these tests are biased is confirmed as well. Another significant impact of standardized testing is the involvement of private citizens in the education business. Mok (2009) explains that when the Chinese government realized that the state alone could not keep up with the increasing demand for higher education, it allowed non-governmental institutions to get involved. These institutions are the last resort for the Chinese students who cannot pass the National College Entrance Examination. Admission criteria for such institutions are rather relaxed, therefore, attracting significant number of students. However, with the increasing tuition fee of such institutions, economic burden on the parents is significant, also adding to the inequality of access to education, promoting an elitist system. 
In the case of China, government controlled examinations remain important but their influence has been declining. Tests are no longer crucial to providing further educational and career opportunities. United States is one of the few nations going back to standardized testing when countries with the most history with it are struggling to get out of it. Standardized testing does not necessarily provide accountability for student failure because of its disregard for cultural, social, gender, and linguistic biases in its format. When the government controls the curriculum and the education, it controls the future. Innovation and creativity become less desired characteristics but test-taking skills become more valuable. It creates education elites while increasing the gap in social and economic inequality. China, Korea, Japan, and Taiwan are few of the many nations that are struggling because of the lack creativity and innovation in their schools.

Standardized testing leads to creation of a national curriculum. National curriculum brings government more control over what is being taught and by whom. Then, with a government designed culturally, socially, politically, and economically biased curricula, the role of formal schooling decreases, thus creating a need for supplementary programs to prepare the nation's students for the tests. These supplementary programs create an elitist society, reducing the level of creativity and innovation within the nation's schooling. With an elitist education system, the emphasis on standardized testing increases. It is a cycle difficult to stop or intervene because of its complexity already engrained in the society. These educational policies are "particularly important expressions of social power in that they convey the values of authoritative actors and institutions whose particular forms of knowledge about the social world are reflected in these texts" (Ball, 1990, p. 17)

\section{AUTHOR BIOGRAPHY}

Dr. Ozturgut is a leader in International Education and Entrepreneurship field. He has extensive experience in teaching and conducting research across continents. He is currently an Assistant Professor in the unique International Education and Entrepreneurship PhD program at the University of the Incarnate Word, San Antonio, Texas. His research interests include Chinese Higher Education, Internationalization of Higher Education in the U.S., and Comparative and International Higher Education.

\section{REFERENCES}

1. Bray, M. (2007). The shadow examination system: Private tutoring and its implications for planners. UNESCO International Institute for Educational Planning, Paris 2007, 1-101.

2. Foucault, M. (1984). The means of correct training. In P. Rabinow (ed.), The Foucault Reader (New York: Pantheon), 188-205.

3. Hwang, G. (1999). Korean National Curriculum. National Institute for Educational Research.

4. Kim, S. \& Lee, J.H. (2006). Changing facets of Korean higher education: Market competition and the role of the State. Higher Education, 52(3), 557-587.

5. $\quad$ Kandel, I.L. (1936). Comparative education, Review of Educational Research, 6, p. 401.

6. Kandel, I.L. (1933). Studies in comparative education. London/Bombay/Sydney: George Harrap and Co.

7. Korea Ministry of Education, Science, and Technology (2011) Education in Taiwan, 2010-2011, Retrieved on February 14, 2011 from http://english.mest.go.kr/web/1721/site/contents/en/en_0219.jsp

8. Kwong, J. (1997). The Political Economy of Corruption in China.

9. Linn, R. (1987). Accountability: The comparison of educational systems and the quality of test results. Educational Policy, 1(2), 181- 198.

10. Madaus, G. F. (1991). The effects of important tests on students. Phi Delta Kappan, 73(3), 226-231.

11. Mok, K.H. (2009). The Growing Privateness in China's Higher Education: Challenges and Policy Implications. Compare, 39(1), 35-49.

12. Psacharopoulos, G. and S. Tassoulas (2004), Achievement at the higher education entry examinations in Greece: A Procrustean approach, Higher Education, 47, 241-252.

13. Resnick, L. B., \& Resnick, D. P. (1989, October). Tests as standards of achievement in schools. Paper presented at the Invitational Conference of the Educational Testing Service, New York, NY.

14. Tse-tung, M. (1935). On the correct handling of contradictions among the people. Selected Readings.

15. Niu, W. (2007). Western influences on Chinese educational testing. Comparative Education, 43(1), 71-91.

16. Wiggins, G. (1989). A true test: Toward more authentic and equitable assessment. Phi Delta Kappan, 70(9), 703-713. 
NOTES 